\title{
Construction of Future Classroom in Primary School
}

\author{
Weimin $\mathrm{Wu}^{1, \mathrm{a}}$, Xiaoping $\mathrm{Liu}^{2, \mathrm{~b}}$ \\ ${ }^{1}$ Department of Education Technology, Qingdao University, Qingdao, 266071, China \\ ${ }^{2}$ Teachers College, Qingdao University, Qingdao, 266071, China \\ aemail: woogle@163.com, bemail: iamliuxiaoping@163.com
}

Keywords: Future Classroom; Primary School; Construction; Traditional Classroom

\begin{abstract}
Primary school is the foundation of an individual's formal education. It is a prerequisite of the construction research to create an elementary school classroom environment that is comfortable, productive and suitable for children's development. Future classroom is the major starting point of basic education conducted in classrooms. According to scientific theories and actual requirements we do the research for exploring future classroom's features and functions, which differs from those of traditional classroom. We put more emphasis on future classroom's people-orientation, harmony with nature, high intelligence, openness and frequent interaction etc. At last, we construct an ideal mode of future classroom consisting of physical architecture, resources and media, and teaching models.
\end{abstract}

\section{Introduction}

As the basis of compulsory education, primary school has a big influence on one's growing up. The classroom, main place for teaching and learning, is usually teacher-centered although the teaching model changes a lot with the development of modern society and technology. The position of desks and chairs in classroom has not been changed and teaching activities are mainly controlled by teachers. Many researches show that this type of learning space can not improve the initiative of students and neither could not adapt to the education reform in modern society [1] [2].

To cultivate innovative talents in the 21st century, the transforming of primary school classroom is becoming more and more important for new curriculum reform. In order to promote students to obtain knowledge and life experiences better, it's of vital necessity to construct a new classroom model. This future classroom should be focused on not only teaching theories but also suitable physical framework and learning equipment.

In recent years, there are more and more classroom reform projects on the intelligent and interactive design of future classroom. In Japan "Computopia1996", it's a kind of future classroom in imagination and in "1990 Ocotillo Retreat", it's a future classroom mode created by a Phoenix College [3]. NASA supported the project "Pennsylvania Department of Education Devon Country Council at the Leigh University Columbia College" [4]. Microsoft supported the project of future classroom called "University of Szeged" [4]. And there are projects of James Madison University, Harrisonburg (Toward a Future Wireless Classroom Paradigm) [5]. There is an Advanced Computer Technology (ACT) laboratory at Middle Tennessee State University Honors College [2] and the project "iRoom" in Stanford University [6].

From all the researches, we can see that the construction of future classroom school puts main emphasis on education principles, rational physical space and the application of modern information technology. At the same time, we should do the designing and experiments of future classroom so that we can put the ideal classroom model into primary school's practical usage according to the three points above.

As new information technology develops, computers bring big changes to educational technology. If we want new technique to do good for learning, educational software should be designed with the aim of learners' objectives, demands, activities and learning circumstances. This methodology for software is called Learner-Centered Design [7]. Although Soloway, Guzdial \& 
Hay raised the method mainly for software designing [7], it still has a very good reference to the design of classroom space and classroom activities.

With the idea being learner-centered, future classroom not only meets the need for complicated styles of communication, but also take its comfort, efficiency and convenience into consideration. From the aspect of compulsory education, it can optimize students' learning environments, promote their innovative skills and exert their deep potentials. As to technology implementation, it can realize the combination of information technology and curriculum and promote primary school class to be more visualized, efficient and modernized. Last but not least, it can make schoolchildren cultivate their own learning skills, practical abilities and cooperation spirit, which has great significance for families, country and the society.

\section{Main Orientation of Future Classroom in Primary School}

Based on deep exploration and new curriculum standards, we should construct a future classroom model built on scientific education theory and modern information technology, which can lead to a new kind of teaching and learning environment that serves and supports class teaching. That is to say, future classroom in primary school centers on free development promoting teaching subject to develop healthily and freely, all construction elements sharing together in harmony at the core.

As cloud computing and network computing fast develop, we can see the influence of computing everywhere in our daily life. A huge learning platform with knowledge net can form diverse learning circumstances and a ubiquitous learning space. In the network combined with learners, learning spaces and learning contents, different kinds of resources are shared in the learning system. Students can gather useful information and launch their learning activities via mobile devices in the space composed of cognitive network and learning styles. Meanwhile, information one gains should be internalized to one's own knowledge net to promote one's ability. So we think patterns of future classroom should be displayed:

\section{A. Electronic resources for learning}

Efficient teaching resources are the basis for learning. Those resources rely on not only teachers' instruction but also on the Internet, CD-ROMs, videos and some more diversified methods. In particular, the Internet provides rich information both theories and practical cases, which can give the most proper learning materials to learners in different levels. It can also help students deepen the understanding of various resources to motivate learners' thirst for knowledge.

\section{B. Students-centered teaching model}

In traditional teaching modes, teacher is the leading role in class teaching activity while students are passive accepters. In digital learning environment, the majority of students can be fully demonstrated. The whole process of learning turns to be individualized with teaching progress fitting in students' learning levels, teaching content fitting in students' learning needs and teaching models fitting in students' learning strategies. In other words, core of learning transforms from teachers to students, which fully satisfies learners' personal learning requirements and interests.

\section{Modularized and Task-driven study}

It is the specific process of digital learning for students' information processing with digital tools. We can use modular theory to blend practical issues in teaching contents with learning modules. Students can conduct their own exploration to improve basic skills of problem solving. Total solutions would be raised by the combination of various materials. Task-driven method can integrate knowledge learning with practical circumstances, which will be good for learners' operational capacity and innovative minds.

\section{Open and intellectualized instructional evaluation}

Teaching evaluation can be designed to get hold of students' understanding, learning quality, application effect as well as communication and cooperation abilities via intelligent computers. It should be open and persuaded not only for teachers' feedback but also for students' self-assessment. Besides, students can give feedback to teachers in time according to the teaching conditions so that both teachers and students can get mutual improvement by effective supervision. 


\section{Features of Future Classroom in Primary School}

With the integration of future classroom research findings at home and abroad, we think that main features of future classroom should be objectified to be humanized, integrated, more open and free, modern intelligent, interactive in learning and teaching, ecologically concordant.

\section{A. Humanism}

Future classroom in primary school should pay close attention to teachers and learners, which consist of the main body of a whole class. As a latest survey of SCUP and corporation, interviewers showed that learners should be the center of learning space [8]. It can be more people-oriented in the design of physical construction.

\section{B. Intelligence}

JISC lunched the report: Designing Spaces for Effective Learning: A Guide to e21st Century Learning Space Design. It mainly discussed the relationship between instructional technology and space innovations [9]. Future classroom in primary school should be a highly intelligent modernized classroom, which makes full use of display devices, data processing equipment, data storage facilities, multimedia equipment, input and output devices and interactive devices.

The class teaching is a mutual process between men and devices with data interaction ports which guarantees students to use intelligent service commodiously. Moreover, large-scale wireless transmission and convenient ME (mobile equipment) can also help students learning everywhere.

In some researches overseas, some scenes are designed that the classroom intelligent system shows which place will hold the lesson and the courses arranged in the day [1]. It will also identify who and when the man entered the classroom or building, class tasks and device activation, class testing and students' research conditions.

\section{Miscibility}

Although we put emphasis on learning in class, some researchers want to combine formal learning with informal learning to expand the classroom studying. There is a mix of multiple teaching activities in future classroom. According to various subjects, it can combine virtual classroom with real classroom to realize the combination between formal class and informal class.

\section{Openness}

The openness of future classroom mainly refers to teaching organized forms and teaching resources sharing. In teaching organized forms, tables and chairs are friendly convenient for various teaching activities; while in teaching resources, teachers and learners can easily get access to resources inside and outside classroom and interact well with information in demand.

\section{E. Ecology}

The ecology of future classroom means harmonious coexistence with the society, opening to the outside world, living in an equal level. The ultimate goal of future classroom is to build a harmonious classroom that adheres to people-oriented and adjusts the relation between education elements to promote students' self-growth, self-reflection and self-improvement.

\section{Functions of Future Classroom in Primary School}

David Miliband once proposed the following features of classroom in the future in school's innovation design: Future classroom should be beautiful, inspirational, adaptable, sustainable, inclusive, fresh, safe, flexible, ICT-enabled, multi-user, fun, delightful, curved, growing and natural [11].In this study, we think that with integrating multiple advanced theories and technologies, future classroom concerning pupils' free development should be:

Fun.a: Future classroom should be a kind of class gathering various information media which is reflected by multi-screen display, multiple media services, non-blind area learning and wireless Internet access.

Fun.b: Future classroom should be a conceptual classroom with 21 century modern features. The design of the class can show more humanized design serving cozy, flexible, effective environment.

Fun.c: The physical space of future classroom should be arranged with flexible desks and chairs compared with traditional classroom. SCUP Scott Webber presented the idea that different teaching 
method should correspond to different learning space [11]. Jamieson also advocated that multiple subjects are involved in the design of learning space [12].New type classroom should be a perfect combination of common classroom and computer lab. It will be compact, spacious and comfortable. According to different subjects and diverse communication modes desks and chairs can be pieced together optionally as needed to achieve best teaching objectives (Fig.1).

\begin{tabular}{|c|c|c|c|c|}
\hline Teaching modes & Instruction & Cooperation & Discussion & Informal \\
\hline Features & Teacher-oriented & $\begin{array}{c}\text { Students } \\
\text { teamwork }\end{array}$ & $\begin{array}{c}\text { Information } \\
\text { sharing }\end{array}$ & $\begin{array}{c}\text { One to one } \\
\text { communication }\end{array}$ \\
\hline $\begin{array}{c}\text { Learning Space } \\
\text { Design }\end{array}$ & $0 \begin{array}{r}0 \\
0\end{array}$ & $\begin{array}{c}0 \\
0\end{array}$ & 0 & 0 \\
\hline
\end{tabular}

Fig.1. Learning space design for different teaching modes

Fun.d: Future classroom should be combined with virtual reality. Every embodiment in the virtual class corresponds to an actual learner. Instructional subjects both virtual and realistic can get involved in online courses in cyberspace.

\section{Teaching Models of Future Classroom in Primary School}

The fostering of every subject and individual has its own peculiarity. Instructional designers should arrange the corresponding classroom teaching mode in accordance with the needs of students' physical and mental traits. Oracle Education Foundation once compared learning in 20th century with learning in 21st century. From the results we can see that learning in 21st century pay more attention to learner-centered and collaborative learning, which stress students to study in emotion and practice. In practical circumstances students can stretch their logical thinking ability and problem-solving ability to conduct their formative evaluation. Elites in 21st century should have knowledge of critical thinking, cross-cultural understanding, initiative minds, teamwork ability, strong interpersonal skills, noble technological literacy and good ability of self-orientation.

Compared with traditional classroom, future classroom gives more priority to students' knowledge exploration process and their independent cooperation. Besides, it tries to stretch students' learning styles, to expand student's learning field and to pay more attention to their emotional experiences that closely connected with real life.

Future classroom should adapt to different subjects such as Chinese, mathematics, English and art. According to traits of the subject and demands of learning, suitable models of teaching should be selected that stick to learner-centered principle and the priority of interaction no matter what kind of the teaching activities are.

Teaching models in future classroom not only include traditional teaching model, but also consist of the research mode, inquiry-based mode, problem-solution mode, "situation-inquiry" mode, game mode, discussion mode, experiential mode and so on. The modes concentrate on students' ability training in various fields with the help of future classroom's physical and psychological construction. At present, researches on teaching models of future classroom are still being studied, which have not come to any uniform conclusion.

\section{Conclusion}

Primary school is the main place for learning at the elementary stage in compulsory education. Traditional classroom has a few shortcomings of being dogmatized, stereotyped, dull and satirized, which is not good for students' quality development. The design of future classroom aims at overcoming the weakness of traditional classroom and give full play to students' dominant role.

According to education principles and the application of modern information technology, we construct a pattern of future classroom that consists of physical space; resources and media; and teaching models (Fig.2).It can create a harmonious learning environment for students' study needs 
by applying best adaptive teaching model to make an effective interaction suiting different kinds of knowledge communication.

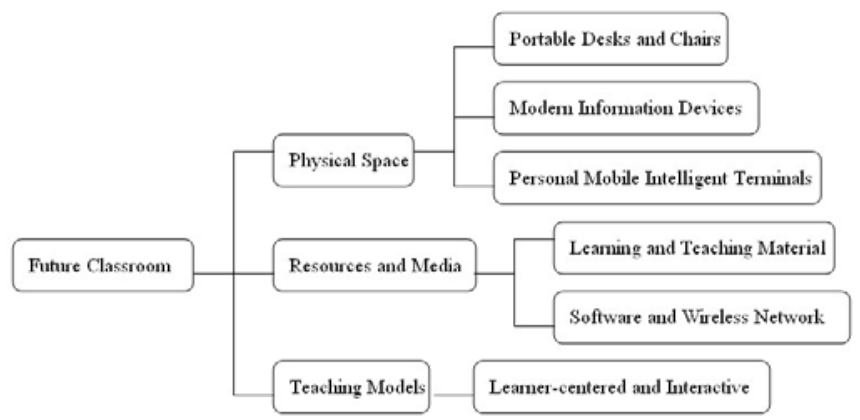

Fig.2. Construction of future classroom

For further study, we can put the future classroom model into teaching practice in primary school in order to explore the feasibility and applicability and improve it better.

\section{Acknowledgement}

This research project was supported by the 2011's Teaching Research Project of Qingdao University under grant number: JY1114.

\section{References}

[1] P. D. Long, S. C. Ehrmann. Future of the Learning Space: Breaking Out of the Box. [C]EDUCAUSE Review, 2005:40 (4):42-58.

[2] J. A. Gilbert. Development of an Advanced Classroom Technology Laboratory: An Incubator for Next Generation Learning. [J]. MERLOT Journal of Online Learning and Teaching, 2008:4 (1):51-55.

[3] Classroom of the Future. http://www.mcli.dist.maricopa.edu/ocotillo/classroom/index.html.

[4] G. Molnar. New ICT Tools in Education-Classroom of the Future Project, Dragan Solesa ed. The Fourth International Conference on Informatics Educational Technology and New Media in Education[C]. Sombor Szerbia.2007: 332-339.

[5] Y. B. Choi, T. A. Abbott, M. A. Arthur, D. N. Hill. Toward a Future Wireless Classroom Paradigm. [J].International Journal of Innovation and Learning, 2007:4(1):14-25.

[6] iRoom software. http://iwork.stanford.edu.

[7] E. Soloway, M. Guzdial, K. E. Hay. Learner-centered design: The challenge for human computer interaction in the 21st century.[J]. Interactions, 1994:1(1):36-48.

[8] C. Johnson, C. Lomas. Design Principles of the Learning Space: Learning and Design Principles, EDUCAUSE Review[C], 2005:40 (4):16-28

[9] JISC. Designing Spaces for Effective Learning: A Guide to e21st Century Learning Space Design. [C].UK: HEFC, 2006.

[10] Innovative designs for schools. http://www.teachernet.gov.uk/.

[11] L. Scott-Webber. Environmental Behavior Research and the Design of Learning Spaces. [A]. SCUP. 2004.

[12] P. Jamieson. Understanding a Happy Accident: Learning to build new learning environments. Report of ECE Research Project on Learning Communities, TEDI, The University of Queensland, 2005. 